\title{
Decompression-metamorphism of Dabie Complex and rapid tectonic-uplift from deep level of the orogenic belt*
}

\author{
CHEN Nengsong (陈能松) $)^{1,2}$, YOU Zhendong (游振东) $)^{1}$ \\ and SUN Min (孙 敏) ${ }^{2}$ \\ (1. Faculty of Earth Sciences, China University of Geosciences, Wuhan 430074, China; \\ 2. Department of Earth Sciences, University of Hong Kong, Hong Kong)
}

Received July 31, 1997

\begin{abstract}
The Dabie Complex can be divided into two metamorphic facies belts, granulite facies and amphibolite facies. Growth zoning in the inner segments of garnets is well preserved in the granulite belt. By contrast, garnets in the amphibolite belt have no composition variations in the inner segments, but show growth zoning in the outer segments. This may imply different incipient metamorphic history for the two metamorphic belts. However, both reaction textures and composition trends that reflect the decompression process are commonly in both of the two belts. Pressure decreased about 0.70 and $0.85 \mathrm{GPa}$ for the granulite and the amphibolite belts, respectively, estimated from mineral thermobarometers. The metamorphic $P-T$ paths are characteristic of collision and subduction, implying that the Dabie Complex underwent rapid subsidence and rapid tectonic uplift. Uplift of the ultrahigh pressure eclogites in the region could also be related to the process.
\end{abstract}

Keywords: Dabie Complex, granulite facies, decompression-metamorphism, tectonic-uplift, P-T path.

Ultrahigh pressure eclogites in the Dabie Mountains and in Jiangsu and Shandong provinces have attracted interest of geologists worldwide and become a hot research area in recent years. The metamorphic rock systems developed in the Dabie Mountains are dominated by metasupracrustal rocks, and are the products of long-term metamorphism, tectonic evolution, and magmatic activities in the deep region of the orogenic belt. Therefore these systems recorded a lot of information about high-pressure metamorphism, which can help reveal a long and complicated metamorphic history and tectonic processes and constrain the formation and evolution of the eclogite in the region. Based on the study of reaction texture, variation of mineral composition, temperature-pressure conditions and evolution ( $P-T$ path), this paper will discuss the dynamic process of rapid uplift from the deep level of the Qinling-Dabie orogenic belt .

\section{Distribution of regional metamorphic belts}

Dabie Complex refers to the intermediate-high grade metamorphic terrane, which is distributed in a wide area bounded by the Macheng fault in the west and extends to the east near to the Tan-Lu fault. In the north and south, the complex is also bounded by nearly east-west trending large-scale ductile fault zones (fig. 1). Rocks of granulite facies occur in the center of the Complex, outward surrounded by rocks of upper and then lower amphibolite facies. The granulite facies rocks often appear as scattered lenticules or discontinuous layers in felsic gneisses or leptite. Amphibolite facies rocks usually outcrop as continuous or discontinuous layers. Rocks near to the

* Project supported by the National Natural Science Foundation of China (Grant No. 49290100) and RGC from University of Hong Kong. 


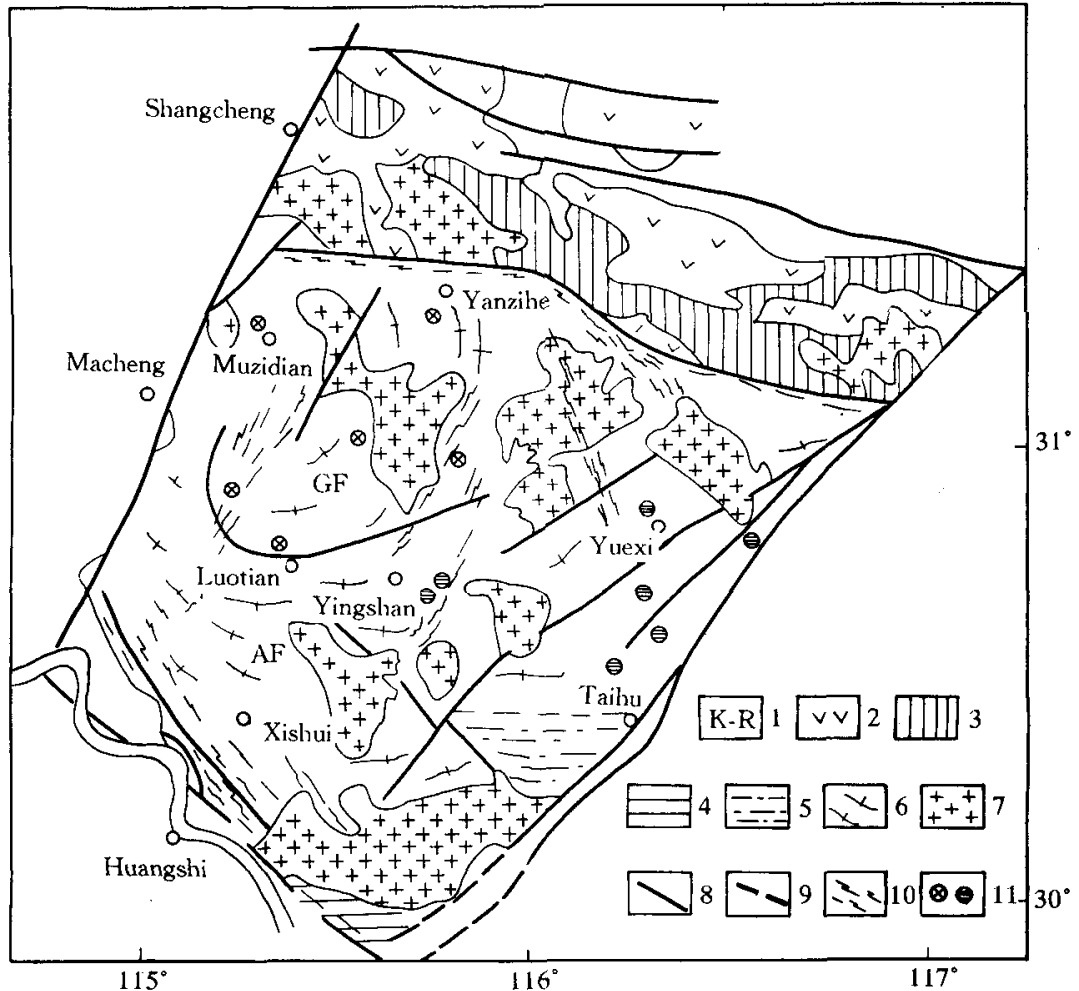

Fig. 1. Geological map of the Dabie Complex (modified after Sou, 1993). GF and AF are the granulite facies and amphibolite facies, respectively. 1, Cretaceous-Tertiary; 2, Jurassic volcanics; 3, Paleozoic rocks; 4, Suixian Group; 5 , Hong' an Group and Susong Group; 6, Dabie Complex; 7, granite; 8, fault; 9, limit of block basement; 10, ductile shear zone; 11, granulite/eclogite occurrences.

Yangtze River show straight schistosity or gneissoid fabrics, and some are highly enriched in $\mathrm{Al}$. This indicates that at least some of the rocks in the amphibolite facies are compositionally different from those in the granulite facies.

\section{Decompressional metamorphic reactions}

Microtexture of decompressional metamorphism is well developed in the granulite facies and amphibolite facies rocks, including (i) symplectite and corona formed by breaking down of garnet, (ii) polymorph transition of kyanite, and (iii) decomposition of kyanite, gedrite, and staurolite. Typical metamorphic reactions in the two metamorphic belts are presented in table 1. Most reactions having plagioclase and/or cordierite as products, and polymorph of $\mathrm{Al}_{2} \mathrm{SiO}_{5}$ transforming from kyanite to sillimanite, and ilmenite, instead of magnetite, as a metallic mineral product of garnet decomposition are the typical evidence for decompression rather than oxidization. These reactions are all related to decompressional retrograde metamorphism ${ }^{[1,2]}$. Photos of some typical reaction textures are shown in figure 2 .

\section{Variation of mineral composition during decompressional process}

A composition profile of a garnet porphyroblast, peak metamorphic minerals and symplectitic minerals have been analyzed by a JEOL-733 superprobe at China University of Geosciences, Wuhan. The variation in mineral compositions strongly reflects the process of decompressional 
metamorphism. Analytical data are not represented in this paper, however, these data can be obtained from the first author.

Table 1 Typical decompression reactions in granulite facies and amphibolite facies rocks

\begin{tabular}{|c|c|c|c|c|}
\hline $\begin{array}{c}\text { Facies } \\
\text { belt }\end{array}$ & Rock type & $\begin{array}{c}\text { Sample } \\
\text { No. }\end{array}$ & Reaction & $\begin{array}{c}\text { Reaction } \\
\text { No. }\end{array}$ \\
\hline \multirow{6}{*}{ Granulite } & \multirow{3}{*}{ felsic } & \multirow{3}{*}{ D9204-1 } & $\mathrm{Grt}+\mathrm{SiO}_{2} \rightarrow \mathrm{Crd}+\mathrm{Qtz}$ & 1 \\
\hline & & & $\mathrm{Grt}+\mathrm{Qtz} \rightarrow \mathrm{Hy}+\mathrm{Crd}+\mathrm{Pl}$ & 2 \\
\hline & & & $\mathrm{Grt}+\mathrm{Kfs}+\mathrm{H}_{2} \mathrm{O} \rightarrow \mathrm{Hy}+\mathrm{Crd}+\mathrm{Bt}$ & 3 \\
\hline & \multirow{3}{*}{ basic } & D9203-10 & $\mathrm{Grt}+\mathrm{Cpx}+\mathrm{H}_{2}(\mathrm{O} \rightarrow \mathrm{Hy}+\mathrm{Hbl}+\mathrm{Pl}+\mathrm{Qtz}+\mathrm{Ilm}$ & 4 \\
\hline & & D) $9208-4$ & $\mathrm{Grt}+\mathrm{H}_{2} \mathrm{O}+\mathrm{Qtz} \rightarrow \mathrm{Hbl}+\mathrm{PI}$ & 5 \\
\hline & & D921-2 & $\mathrm{Grt}+\mathrm{Qtz} \rightarrow \mathrm{Opx}+\mathrm{Pl}+\mathrm{Ilm}$ & 6 \\
\hline \multirow{6}{*}{ Amphibolite } & pelitic and/or & 199204 & $\mathrm{Grt}+\mathrm{Bt}+\mathrm{H}_{2} \mathrm{O} \rightarrow \mathrm{Pl}+\mathrm{Bt}+\mathrm{Ms} \pm$ Sil & 7 \\
\hline & quartzofeldsparthic & I)9225 & $\mathrm{Ky} \rightarrow \mathrm{Sil}$ & 8 \\
\hline & $\mathrm{Mg}-\mathrm{Al}$ rich & D9239-1 & $\mathrm{Ged}+\mathrm{Ky}+\mathrm{Qtz} \rightarrow \mathrm{St}+\mathrm{Crd}$ & 9 \\
\hline & \multirow{2}{*}{ Al-rich basic } & \multirow{2}{*}{ D5432 } & $\mathrm{Ky}+\mathrm{Hbl}+\mathrm{Qtz} \rightarrow \mathrm{St}+\mathrm{Pl}$ & 10 \\
\hline & & & $\mathrm{Grt}+\mathrm{Qtz}+\mathrm{H}_{2} \mathrm{O} \rightarrow \mathrm{Hbl}+\mathrm{Ged}+\mathrm{Pl}$ & 11 \\
\hline & basic & D9501 & $\mathrm{Grt}+\mathrm{Qtz}+\mathrm{H}_{2} \mathrm{O} \rightarrow \mathrm{Hbl}+\mathrm{Pl}$ & 5 \\
\hline
\end{tabular}

$\rightarrow$ stands for reaction relation only, on its left is the first generation with comparatively high pressure. On the right the second one with lower pressure, Grt, garnet; $\mathrm{Hy}$, hypersthene; Cpx, clinopyroxene; $\mathrm{Hbl}$, hornblende; Bt, biotite; Ms, muscovite; Sil, sillimanite; Ky, kyanite; St, staurolite; Crd, cordierite; Ged, gedrite; Kfs, K-feldspar; Pl, plagioclase; Qtz, quartz; Ilm, ilmenite.
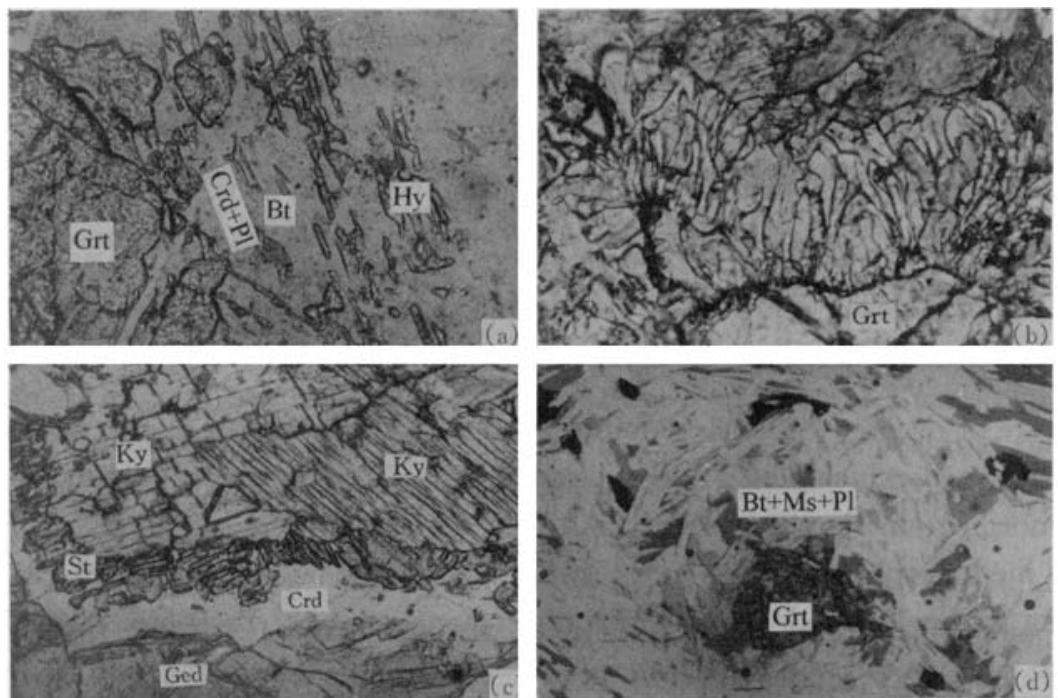

Fig. 2. Microphotographs of the typical decompression reaction textures. (a) Symplectite with hypersthene, cordierite, biotite, plagioclase and quartz of the garnet porphyroblast (D920+-1); (b) garnet decomposed to symplectite with hypersthene, clinopyroxene and plagioclase (D9203-10); (c) staurolite and cordierite coronas around a kyanite included within gedrite (D9239-1) ; (d) garnet decomposed to muscovite, biotite, plagioclase and quartz intergrowth showing post-tectonic crystallization (D9214-1). Photo length is $0.6 \mathrm{~mm}$ for (a) and (b), $1.2 \mathrm{~mm}$ and $3.0 \mathrm{~mm}$ for (c) and (d), respectively.

\subsection{Garnet composition zoning}

Garnet in felsic granulite (D9204-1) has two segments of composition zoning (fig. 3(a)). In 
the inner segment, spessartine $\left(X_{\mathrm{Sps}}\right)$ content decreases outward, characterized by a growth zoning $^{[3,4]}$. Meanwhile, almandine $\left(X_{\mathrm{Alm}}\right)$ content decreases, pyrope $\left(X_{\mathrm{Pyr}}\right)$ and $\mathrm{Mg} / \mathrm{Fe}$ ratio increase, and grossular $\left(X_{\mathrm{Grs}}\right)$ content is almost constant. In the outer segment, $\left(X_{\mathrm{Alm}}\right)$ and $\left(X_{\mathrm{Sps}}\right)$ show an opposite variation outward, and $\left(X_{\mathrm{Grs}}\right)$ and $\mathrm{Mg} / \mathrm{Fe}$ ratios decrease. The composition variation in the outer segment results from decomposition of garnet to symplectitic plagioclase, recording a pronounced decompression history ${ }^{[1,2]}$.
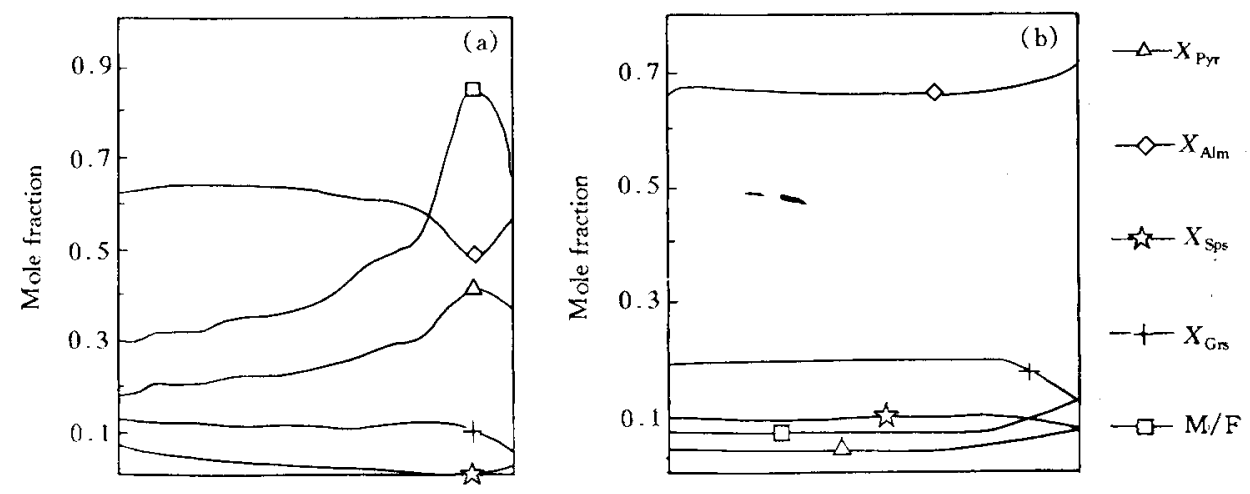

Fig. 3. Composition profiles of the garnet porphyroblases for Huangtuling felsic granulite (20 analytical points) (a) and for Fenghuoshan gneiss ( 37 analytical points)(b).

In the amphibolite facies belt, composition profile of garnet in garnet-kyanite-two mica-plagioclase gneiss is complicated (fig. 3(b)) $. X_{\mathrm{Pyr}}, X_{\mathrm{Alm}}$ and $\mathrm{Mg} / \mathrm{Fe}$ ratios are constant in the inner segment, but increase in the outer segment, whereas $X_{\mathrm{Sps}}$ and $X_{\mathrm{Grs}}$ decrease in the outer segment. These composition variations in the outer segment can also be considered as growth zoning, implying a temperature increase during the decomposition process. Results of elemental scan for another garnet also show that $X_{\mathrm{Grs}}$ decreases and $X_{\mathrm{Sps}}$ increases near to the rim. This is related to the formation of symplectite of muscovite + biotite + plagioclase $+/-$ sillimanite due to decomposition of garnet during the decompressional process.

\subsection{Composition variation of other minerals}

From the first to second generation, plagioclase $X_{\text {An }}$ increases from $22 \%$ to $32 \%$ in felsic granulite, and increases from $35 \%$ to $74 \%$ in basic granulites. In the garnet-kyanite-two micaplagioclase gneiss (from the amphibolite belt), $X_{\mathrm{An}}$ of the matrix plagioclase is $11 \%$ in the core, and $17 \%$ near to the rim which is close to that of the symplectitic plagioclase (20\%). Under the condition of small variation of temperature, the $X_{\text {Grs }}$ decrease in garnet and the $X_{\mathrm{An}}$ increase in plagioclase indicate the decomposition metamorphism of rocks made of garnet + plagioclase + kyanite + mica and quartz ${ }^{[1]}$. Content of $\mathrm{Al}_{2} \mathrm{O}_{3}$ in hypersthene decreases from $6.23 \%$ in the core to $4.74 \%$ in the rim and further to $2.53 \%$ in the symplectite in weight, indicating a cooling process $^{[4]}$. Moreover, matrix biotite has exsolution of rutile in a netted pattern which is known as sagenite texture while symplectitic biotite has no such exsolution. This tells that primary biotite is rich in $\mathrm{T}_{\mathrm{i}}$ and formed at higher temperature, whereas the symplectitic biotite formed at a lower temperature. In summary, composition variation in the two generation solid solution minerals shows a decompressional metamorphic process after the peak metamorphism. 


\section{$4 \quad P-T$ estimation for the extent of decompression}

In this study, we calculated $P-T$ data for peak and retrograde metamorphic mineral assemblages in the felsic granulite (D9204-1), a basic granulite (D9241-2) and a garnet-kyanite-two mica-plagioclase gneiss (D9214-1), following Berman's multiple phases geothermobarometer approach $^{[5]}$. Peak metamorphism of D9204-1 is calculated from garnet composition at the highest $\mathrm{Mg} / \mathrm{Fe}[$ or $\mathrm{Mg} /(\mathrm{Mg}+\mathrm{Fe})]$ point, highest $\mathrm{Al}_{2} \mathrm{O}_{3}$ in the matrix hypersthene, plagioclase, biotite and $\mathrm{K}$ feldspar. Retrograde metamorphism of this sample is calculated from composition of garnet rim, symplectitic hypersthene, cordierite, plagioclase and biotite, and matrix K feldspar (assume no or very little variation in $\mathrm{K}$ feldspar). Peak metamorphism of D9241-2 is calculated from composition of garnet core, matrix hypersthene, clinopyroxene, plagioclase and quartz. Peak metamorphism of D9214-1 is calculated from garnet core, matrix plagioclase, muscovite included in quartz, relic biotite, kyanite and quartz. Retrograde metamorphism of this rock is calculated from garnet rim, symplectitic biotite, muscovite, plagioclase, and quartz.

Calculated peak conditions are $(850 \pm 50)^{\circ} \mathrm{C}$ and $(1.35 \pm 0.1) \mathrm{GPa}$ for D9204-1, (880 \pm $50)^{\circ} \mathrm{C}$ and (1.27 \pm 0.1$) \mathrm{GPa}$ for D9241-2, and $686^{\circ} \mathrm{C}$ and $1.38 \mathrm{GPa}$ for D9214-1. Calculated retrograde metamorphic conditions are $(0.63 \pm 0.1) \mathrm{GPa}$ and $(750 \pm 60)^{\circ} \mathrm{C}$ for $\mathrm{D} 9204-1$, and $0.83 \mathrm{GPa}$ and $6511^{\circ} \mathrm{C}$ for D9214-1. These indicate that (i) some mineral compositions imply highpressure information, although there is not preservation of diagnostic high-pressure mineral association; (ii) there is no much temperature variation during the retrograde process in the two facies belts, but extents of decompression are quite different, i.e. $\Delta P \approx-0.71 \mathrm{GPa}$ for D9204-1 (from granulite) and - 0.45 GPa for D9214-1 (from amphibolite facies). If we consider the occurrence of sillimanite, the $\Delta P$ should be about $-0.85 \mathrm{GPa}$ in amphibolite facies rocks.

\section{Discussion and conclusions}

\subsection{Nature of garnet zoning and its tectonic significance}

- $\mathrm{Mn}, \mathrm{Mg}$, and $\mathrm{Fe}$ are easy for volume diffusion in garnet crystal, and the homogenization temperature for them is between 600 and $750^{\circ} \mathrm{C}^{[6]}$. Mn profile in the inner segment of the garnet from felsic granulite shows characteristics of growth zoning, whereas $\mathrm{Mn}$ is reabsorbed in the outer segment of the garnet during the decomposition reaction around the garnet porphyroblast. Preservation of the garnet growth zoning requires a short time period for granulite metamorphism. In other words, the granulite could not have a long residence time in the lower crust. This also implies that the garnet growth and decomposition are two processes of the same metamorphic event. The P-T path based on this consideration is that the incipient temperature and pressure progressively increase along a curve parallel to the pure transition reaction with constant $X_{\mathrm{Grs}} / X_{\mathrm{An}}$ ratio (coefficient $K$ for such a reaction is constant ${ }^{[1]}$ ), and reach the maxima $\left(P_{\max }\right.$ and $T_{\max }$ ) at the same time, and then pressure decreases at about a constant temperature (figure 4 ).

Constant compositions in the inner segment of the garnet from garnet-kyanite-two mica-plagioclase gneiss (D9214-1) could be due to one of the following reasons: (i) early metamorphic reaction was so slow that the growing garnet can be homogenized by volume diffusion at any time, or (ii) the garnet had a long resident time in the high temperature region, so the incipient growth zoning was rehomogenized. No matter which is the real cause, the garnet in amphibolite facies rocks must have a different development history from that in the granulite facies rocks. 
Considering the distinctive differences in lithological association, we propose that the granulite facies belt and the amphibolite facies belt (especially the amphibolite subfacies near the Yangtze River) belong to two metamorphic terranes. Wang ${ }^{[7]}$ and Chen et al. also discussed the differences between the south Dabie terrane and the north Dabie terrane. Outer segment of the garnet from D9214-1 shows growth zoning, but $X_{\mathrm{Grs}}$ strikingly decreases near to the rim and $X_{\mathrm{An}}$ in matrix plagioclase sharply increases accordingly, indicating a strong decompression. The $P-T$ path of the garnetkyanite-two mica-plagioclase gneiss has the same pattern as that of the felsic granulite (figure 4).

\subsection{Geodynamics of the rapid uplift}

The well-preserved decompressional microtextures in the granulite facies and amphibolite facies rocks of the Dabie Complex provide important petrographic evidence for tectonic uplift in the region. Extent of decompression is about $0.7-0.85 \mathrm{GPa}$ estimated from geothermobarometer and mineral association. This means that about $22-\mathbf{k m}$-thick crustal materials would have been eroded away if the uplift is due to isostatic adjustment of

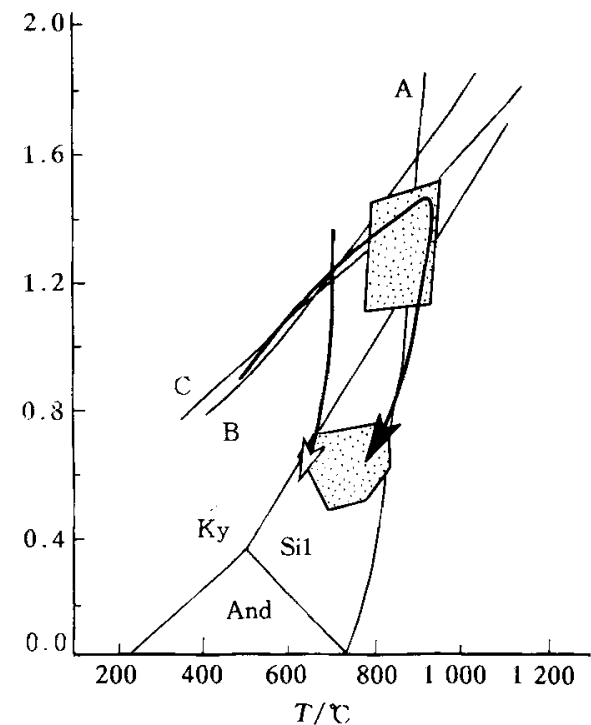

Fig. 4. The $P-T$ path for the typical granulite facies rocks (solid arrow) and amphibolite facies rocks (open arrow). A, 2Alm $+2 \mathrm{Phl}+6 \mathrm{Qtz}=2 \mathrm{Pyr}$ $+2 \mathrm{Kfs}+3 \mathrm{Fsl}+2 \mathrm{~W} ; \mathrm{B}, 4 \mathrm{Alm}+2 \mathrm{Grs}+2 \mathrm{Phl}+2 \mathrm{Kfs}$ $+2 \mathrm{~W}=3 \mathrm{En}+6 \mathrm{An}+4 \mathrm{Ann} ; \mathrm{C}, 4 \mathrm{Alm}+2 \mathrm{Grs}+2 \mathrm{Kfs}$ $+2 \mathrm{~W}=3 \mathrm{Fsl}+6 \mathrm{An}+\mathrm{Ann}$. The shadow polygonal areas are the $P-T$ condition range of peak for granulite facies metamorphism and the retrograde metamorphism respectively.

continental crust with a normal density. However, there is no sedimentation evidence for such an erosion.

The maximum temperature and maximum pressure reached on the path contemporaneously for the felsic granulite. This is similar to metamorphism caused by subduction process ${ }^{[8]}$, but is different from the fact that continent-continent collision which is characterized by the maximum temperature reached with a pronounced pressure dropping from its maximum ${ }^{[9]}$. However, it has non-hair pin type $P-T$ path (decreasing pressure at about constant temperature) and so is different from that with subduction, but more like that with collision. Up to date, well-preserved garnet growth zoning formed between 700 and $800^{\circ} \mathrm{C}$ is only reported for the semi-in situ metapelite in eastern Grenville Province of the Canadian Shield ${ }^{[10]}$. There the hair pin type $P-T$ path is derived from garnet, implying that the metapelite and metabasic rocks underwent rapid uplift after high temperature-high pressure metamorphism (eclogite facies) with subduction, so the growth zoning is preserved. Garnet growth zoning preserved in the Dabie Complex implies that the rapid uplift was driven by the tectonic movement after peak metamorphism. Huge volume of the Complex and high temperature can explain the slow cooling rate.

\subsection{Decompressional metamorphism of the granulite and the uplift of eclogite}

There are three kinds of views on the metamorphic age of the Dabie eclogites: (i) Indosinian, about $220 \mathrm{Ma}^{[11-14]}$; (ii) Caledonian, about $450 \mathrm{Ma}$; (iii) Jinningian period, about $800-$ $1000 \mathrm{Ma}^{[15]}$. In the distribution areas of the granulite, there is no finding of eclogite so far, but the following considerations suggest that uplift of the eclogite and the granulite may be related to 
(i) both eclogite and granulite (as wide as the whole Dabie Complex including amphibolitic rocks) underwent extensive retrograde metamorphism. Some coesite eclogite even underwent granulite metamorphism during decompression with an increasing temperature ${ }^{[16]}$, the retrograde condition is similar to that for granulite; (ii) highly deformed Huilanshan granite has $227 \mathrm{Ma}$ U-Pb zircon concordia age, but in the country basic granulite there is no deformation for symplectite of garnet. This supports that the retrograde metamorphism of decomposition of garnet to products with hypersthene happened after $227 \mathrm{Ma}^{[17]}$, consistent with the youngest metamorphic age of the eclogite. The $1700 \mathrm{Ma}$ lower intercept age of single zircon from the felsic granulite from Huangtuling was once interpreted as metamorphic age for the granulite. However, the preservation of the garnet growth zoning challenges this point of view. It awaits further study to tell whether multiple phases of granulite metamorphism happened in the region. Based on this study, we tentatively propose that metamorphism for the granulite with garnet growth zoning and that for the eclogite happened in the same tectonic event but in different settings, the former in arc-continent collision environment while the latter is related to subduction. They both rapidly uplifted after peak metamorphism. The earlier uplifted eclogite was superimposed by granulite metamorphism, while some other eclogite uplifted after granulite was cool.

Acknowledgement The authors would like to thank Prof. Zhang Guowei, the key-project manager in chief for the guidance, and Department of Earth Sciences of HKU and Qui Jie and Zhang Yuanxiang for their assistance and support.

\section{References}

1 Harley, S. L., The origins of granulites: a metamorphic perspective, Geol. Mag ., 1989, 126:215.

2 Chen, N. S., Decompression metamorphic mineral assemblages and decompression metamorphic reaction, Science and Technolohy Information in Geology (in Chinese), 1989, 8(4):21.

3 Loomis, T. P., Composition zoning of crystals: a record of growth and reaction history, in Kinetics and Equilibrium in Mineral Reactions (ed. Saxena, S. K.), New York; Springer-Verlag, 1983, $1-60$.

4 Pattison, D. R. M., Begin, N. J., Zoning patterns in orthopyroxene and garnet in granulites: implications for geothermometry, J. Metamorphic Geol., 1994, 12:387.

5 Berman, R. G., Thermobarometry using multiequilibrium calculations: a new technique with petrologic applications, Canadian Mineralogist, 1991, 29:833.

6 Spear, F. S., Selverstone, J., Hicmoff, D. et al., P-T paths from garnet zoning: a new technique for deciphering tectonic processes in crystalline terranes, Geology, 1984, 12:87.

7 Wang, X., Liou, J. G., Mao, H. K., Coesite-bearing eclogite from Dabie Mountains in Central China, Geology, 1989, $17: 1085$.

8 Ernst, W. G., Tectonic history of subduction zones inferred from retrograde blueschists $P-T$ paths, Geology, 1988, 16: 1081 .

9 England, P. C., Thompson, A. B., Pressure-temperature-time paths of regional metamorphism I: Heat transfer during the evolution of thickened continental crust, $J$. Petrology, 1984, 25:894.

10 Indares, A., Metamorphic interpretation of high-pressure-temperature metapelites with preserved growth zoning in garnet, eastern Grenville Province, Canadian Shield, J. Metamorphic Geology, 1995, 13; 475.

11 Ames, A., Zhou, G., Xiong, B., Geochronology and geochemistry of ultrahigh-pressure metamorphism with implications for collision of the Sino-Korean and Yangtze Cratons, central China, Tectonics, 1996, 15(27):472.

$12 \mathrm{Li}, \mathrm{S}$, , Chen, Y., Cong, B. et al., Collision of the North China and Yangtze Blocks and formation of coesite-bearing eclogites: Timing and processes, Chemical Geology, 1993, 109:70.

13 Chavagnac, V., Bor-ming Jahn, Sm-Nd isotopic ages and geochemical characteristics of the Bixiling complex, Dabie Mountains, China, Chinese Science Bulletin, 1995, 40(supplement): 126.

14 Liou, J. G., Wang, Q., Zhang, R. Y. et al., Ultrahigh- $P$ metamorphic rocks and their associated lithologies from the Dabie Mountains, Central China: A field trip guide to the 3rd International Eclogite Field Symposium, Chinese Science Bulletin, 1995, 40( suppl. ) : 1 .

15 Liu, R.X., Fan, Q., Li, H. M. et al., Chronological study of high-pressure metamorphism of gamet-bearing peridotite-eclogite in Bixiling, Dabie Mountains, Chinese Science Bulletin (in Chinese), 1995, 40:1304.

16 Wang, Q., Ishiwatari, A., Zhao, Z. et al. Coesite-bearing granulite retrograded from eclogite in Weihai, eastern China: a preliminary study, European Journal of Mineralogy, 1993, 5:141.

17 Chen, N. S., You, Zh. D., Suo, S. T. et al., Zircon U.Pb ages of felsic granulite and deformed granite from Dabie Mountains, Chinese Science Buletin (in Chinese), 1996, 41:1009. 